\title{
THE IMPACT OF MORPHOLOGICAL CHANGES IN SMALL BOWEL MUCOSA ON IRON METABOLISM IN CHILDREN WITH CELIAC DISEASE
}

\author{
Klimov L. Ya. ${ }^{1}$, Stoyan M. V. ${ }^{1,}{ }^{2}$, Kuryaninova V. A. ${ }^{1}{ }^{2}$, Kashnikov V. S. ${ }^{2}$, \\ Botasheva V. S. ${ }^{1}$, Dolbnya S. V. ${ }^{1}$, Asaturova D. V. ${ }^{1}$, Kashnikova S. N. ${ }^{1}$ \\ 1 Stavropol State Medical University, Russian Federation \\ 2 Philippsky Child Clinical Hospital, Stavropol, Russian Federation
}

\section{ВАИЯНИЕ ВЫРАЖЕННОСТИ МОРФОАОГИЧЕСКИХ ИЗМЕНЕНИЙ САИЗИСТОЙ ТОНКОЙ КИШКИ НА ПОКАЗАТЕАИ ОБМЕНА ЖЕАЕЗА У АЕТЕЙ С ЦЕАИАКИЕЙ}

\author{
А. Я. КАимов ${ }^{1}$, М. В. Стоян ${ }^{1,2}$, В. А. Курьянинова ${ }^{1,2}{ }^{2}$ В. С. Кашников ${ }^{2}$, \\ В. С. Боташева', С. В. Аолбня', А. В. Асатурова', С. Н. Кашникова' \\ 1 Ставропольский госуаарственный меАицинский университет, Российская ФеАерация \\ 2 ГороАская Аетская кАиническая больница имени Г. К. ФиАиппского, \\ Ставрополь, Российская ФеАерация
}

A comprehensive study was carried out, which implied clinical and laboratory tests involving 164 children with morphologically proven celiac disease, of which $44(26.8 \%)$ had iron-deficiency anemia (IDA) verified in them; 79 $(48.2 \%)$ had latent iron deficiency (LID), and another $41(25.0 \%)$ revealed no proven signs of iron deficiency (ID). The gastro-intestinal symptoms seen as the initial and most pathognomonic manifestation of celiac disease, are mostly typical of children with IDA. An analysis of the registered complaints and measurements shows that children with IDA have low body weight and height prevailing among them. The children with celiac disease accompanied with ID revealed higher levels of antibodies to tissue transglutaminase. Among children with IDA the severest atrophy of the small intestine mucosa (Stage 3C by Marsh - Oberhuber) was detected in $80.0 \%$ of cases, while among those with no ID only $21.1 \%$ had the same issue. During that, there was also correlation found between the stage of the atrophy and the serum levels of iron $(r=-0.32, p<0.005)$ and serum ferritin $(r=-0.50, p<0.001)$.

Key words: celiac disease, children, serological markers, iron deficiency anemia, latent iron deficiency, atrophy of mucosa

Проведено комплексное клинико-лабораторное обследование 164 детей с морфологически подтверждённой целиакией, из которых у 44 (26,8 \%) верифицирована железодефицитная анемия (ЖДА), у 79 (48,2 \%) латентный дефицит железа (ЛДЖ), а у 41 (25,0 \%) лабораторных признаков дефицита железа (ДЖ) не выявлено. Гастроинтестинальные симптомы как одни из первых и наиболее патогномоничных проявлений целиакии характерны в большей степени для детей с ЖДА. Анализ жалоб и антропометрических показателей демонстрирует, что у детей с ЖДА превалирует дефицит массы тела и низкий рост. У детей с целиакией, сопровождающейся ДЖ, выявлены более высокие уровни антител к тканевой трансглутаминазе. Наиболее глубокая атрофия слизистой оболочки тонкой кишки (стадия 3С по Marsh - Oberhuber) у детей с ЖДА выявлена в 80,0 \% случаев, а у детей без ДЖ - лишь в 21,1 \%, при этом обнаружена корреляция между стадией атрофии и уровнями сывороточного железа $(r=-0,32, p<0,005)$ и сывороточного ферритина $(r=-0,50, p<0,001)$.

Ключевые слова: целиакия, дети, серологические маркеры, железодефицитная анемия, латентный дефицит железа, атрофия слизистой оболочки

T he current view on celiac disease, which is seen as a multifactor autoimmune issue in people with genetic predisposition, induced by gluten, and featuring lesion to the small bowel villi, offers a description not for clinical peculiarities alone yet also inevitable development of various micronutrient deficiency conditions in respective patients [1,9].

Iron absorption in healthy bodies takes place through small bowel [2, 22, 24]. Atrophic changes observed in the small intestinal mucosa in case of celiac disease, flattening of the villi and a decrease in the number of highly differentiated enterocytes, as well deepening of crypts, will naturally be accompanied with reduced iron absorption [20]. This is the factor explaining why iron deficiency (ID) complicates the course of typical celiac disease, which manifests itself in early childhood as a rule $[13,21]$. On the other hand, iron deficiency anemia (IDA) and latent iron deficiency (LID) are the most common extraintestinal manifestations of celiac disease in school-age children and adults $[7,8,17]$.

In view of the controversial data to be found in literature and a sufficient stock of our own clinical and laboratory findings, we carried out an analysis of clinical, serological, and morphological issues related to celiac disease course in children with various types of ID. 
Aim of study: to analyze the link between morphological and clinical-serological factors in children with celiac disease depending on the presence and type of ID.

Material and Methods. Retrospective analysis was carried out concerning case records for 164 children first diagnosed with celiac disease and aged 8 months -17 years (mean age $4.5 \pm 0.3$ yrs) who received in-patient treatment at the Philippsky Child Clinical Hospital Gastroenterology Department (Stavropol, Russia) at certain periods within 2001-2016.

The diagnosis was given subject to the ESPGHAN criteria $(1990,2012)$, which included typical clinical symptoms, from 2004 through 2010 - identification of specific antigliadin antibodies (AGA) of IgA and IgG classes; from 2011 - identification of tissue transglutaminase type 2 antibodies (anti-TG2) IgA and IgG, endomysial antibodies (EMA), morphological study of the empty intestine mucosa (EIM) following the Marsh-Oberhuber classification (Stages 3A-3C). The exclusion criteria were negative titers of specific antibodies, lack of morphological study of the EIM.

Based on the clinical and anamnestic analysis, the typical disease was diagnosed in 148 (90.2 \%) cases, while the number of atypical cases was $16(9.8 \%)$. The patients included 84 (51.2\%) girls and 80 (48.8\%) boys.

ID diagnostics implied a hemogram test, detection of serum iron levels (SI), serum ferritin (SF), serum total iron-binding capacity (TIBC), and transferrin. The reference values for SI were 10.6-33.6 $\mu \mathrm{mol} / \mathrm{I}$, for TIBC $40.6-62.5 \mu \mathrm{mol} / \mathrm{l}$, for SF - 30-120 ng/ml, and 2.03-3.6 $\mathrm{g} / \mathrm{L}$ for transferrin. The transferrin saturation (TSAT) is a value showing the absolute weight of SI in TIBC.

The patients were divided in three groups depending on the presence and the type of ID. The Group 1 included $44(26.8 \%)$ patients with IDA. The Group 2 had $79(48.2 \%)$ children with LID. The Group 3 involved 41 $(25.0 \%)$ children with no ID.

The data were processed with statistical methods involving the software package ATTESTAT, Statistica 10.0 The parametric values at normal data distribution were assessed with the Student's t-test. For abnormal distribution, Mann-Whitney U-test was employed. Non-parametric values were calculated based on the $\chi^{2}$ criterion The relationship between the indices was evaluated through paired correlation coefficient of Pearson ( $r$ ), Spearman. The difference was accepted as significant at $\mathrm{p}<0.05$.

Results and Discussion. The rate of clinical-test proven ID in children in the period of celiac disease clinical manifestation was significantly above the population rate, while the ratio between IDA and LID remained the same, which was $1: 1.9$ in the group that underwent analysis. A detailed analysis revealed an increase in the ID degree along with an increase in the patient's age and the duration of the malabsorption syndrome. The manifestation of celiac disease and first complaints expressed by children with IDA showed up at an average age of $(X \pm m)$ $2.3 \pm 0.5 \mathrm{yrs}$; in children with LID - at the age of $1.8 \pm 0.3$, while in patients with no ID the same factor was $1.6 \pm 0.3$ $(p>0.05)$. During that, the mean age for diagnosing IDA in children was $5.8 \pm 0.8$, which is significantly above the age of diagnosis verification for both children with LID $4.1 \pm 0.4(p<0.05)$, and patients with no ID $-4.0 \pm 0.5$ $(p<0.05)$. The average duration for the latent period at IDA was $3.4 \pm 0.6$ yrs; in children with LID it was $2.3 \pm 0.3$ yrs $(p<0.05)$, while for patients with no ID that index was $2.3 \pm 0.4$ yrs $(p<0.05)$. Naturally enough, a longer course of undiagnosed celiac disease and thus induced malabsorption of the major macro- and micronutrients in the small bowel increases the risk of developing ID.
Out of the patients with celiac disease complicated with IDA in its acute phase, 16 (36.4\%) were boys, and $28(63.6 \%)$ - girls; this balance was different in the group of children with LID - 46 (58.2 \%) boys and $33(41.8 \%)$ girls $(p<0.05)$, while in the group with no ID no significant gender differences were identified with 18 (43.9\%) boys and $23(56.1 \%)$ girls.

The frequency of complaints and clinical symptoms registered in patients with IDA, LID, and with no ID through the active stage of celiac disease can be seen in Table 1.

\begin{tabular}{|c|c|c|c|c|c|c|}
\hline \multirow{2}{*}{$\begin{array}{l}\text { Clinical } \\
\text { symp- } \\
\text { toms of } \\
\text { celiac } \\
\text { disease }\end{array}$} & \multicolumn{3}{|c|}{$\begin{array}{l}\text { Presence and type of } \\
\text { iron deficiency }\end{array}$} & \multicolumn{3}{|c|}{$\begin{array}{l}\text { Difference reliability } \\
\left(\chi^{2}\right)\end{array}$} \\
\hline & $\begin{array}{c}\text { IDA, } \\
\mathrm{n}-44\end{array}$ & $\begin{array}{c}\text { LID, } \\
n-79\end{array}$ & $\begin{array}{l}\text { No ID, } \\
n-41\end{array}$ & $\mathrm{P}_{1}$ & $P_{2}$ & $P_{3}$ \\
\hline \multicolumn{7}{|c|}{ Major symptoms } \\
\hline $\begin{array}{l}\text { Abdom- } \\
\text { inal dis- } \\
\text { tention }\end{array}$ & $\begin{array}{c}24 \\
(54.5 \%)\end{array}$ & $\begin{array}{c}37 \\
(46.8 \%)\end{array}$ & $\left(\begin{array}{c}13 \\
(31.7 \%)\end{array}\right.$ & $>0.05$ & $<0.05$ & $>0.05$ \\
\hline $\begin{array}{l}\text { Diar- } \\
\text { rhea }\end{array}$ & $\begin{array}{c}31 \\
(70.5 \%) \\
\end{array}$ & $\begin{array}{c}42 \\
(53.2 \%) \\
\end{array}$ & $\begin{array}{c}17 \\
(41.4 \%)\end{array}$ & $>0.05$ & $<0.01$ & $>0.05$ \\
\hline $\begin{array}{l}\text { Vomit- } \\
\text { ing }\end{array}$ & $\begin{array}{c}18 \\
(40.9 \%)\end{array}$ & $\begin{array}{c}12 \\
(15.2 \%)\end{array}$ & $\begin{array}{c}5 \\
(12.2 \%)\end{array}$ & $<0.001$ & $<0.001$ & $>0.05$ \\
\hline $\begin{array}{l}\text { Chronic } \\
\text { abdom- } \\
\text { inal } \\
\text { pain }\end{array}$ & $\begin{array}{c}21 \\
(47.7 \%)\end{array}$ & $\begin{array}{c}30 \\
(38.0 \%)\end{array}$ & $(36.6 \%)$ & $>0.05$ & $>0.05$ & $>0.05$ \\
\hline $\begin{array}{l}\text { De- } \\
\text { creased } \\
\text { appe- } \\
\text { tite }\end{array}$ & $\begin{array}{c}18 \\
(40.9 \%)\end{array}$ & $\begin{array}{c}35 \\
(44.3 \%)\end{array}$ & $\left(\begin{array}{c}19 \\
(46.3 \%)\end{array}\right.$ & $>0.05$ & $>0.05$ & $>0.05$ \\
\hline $\begin{array}{l}\text { Low } \\
\text { body } \\
\text { weight }\end{array}$ & $\begin{array}{c}34 \\
(77.3 \%)\end{array}$ & $\begin{array}{c}57 \\
(72.2 \%)\end{array}$ & $(56.1 \%)$ & $>0.05$ & $<0.05$ & $>0.05$ \\
\hline $\begin{array}{l}\text { Low } \\
\text { height }\end{array}$ & $\begin{array}{c}30 \\
(68.2 \%) \\
\end{array}$ & $\begin{array}{c}52 \\
(65.8 \%) \\
\end{array}$ & $\begin{array}{c}17 \\
(41.4 \%) \\
\end{array}$ & $>0.05$ & $<0.05$ & $<0.05$ \\
\hline $\begin{array}{l}\text { Irrita- } \\
\text { bility }\end{array}$ & $\begin{array}{c}19 \\
(43.2 \%) \\
\end{array}$ & $\begin{array}{c}33 \\
(41.8 \%) \\
\end{array}$ & $\begin{array}{c}12 \\
(29.3 \%) \\
\end{array}$ & $>0.05$ & $>0.05$ & $>0.05$ \\
\hline \multicolumn{7}{|c|}{ Minor symptoms } \\
\hline $\begin{array}{l}\text { Consti- } \\
\text { pation }\end{array}$ & \begin{tabular}{|c|}
2 \\
$(4.5 \%)$ \\
\end{tabular} & $\begin{array}{c}11 \\
(13.9 \%) \\
\end{array}$ & $\begin{array}{c}6 \\
(14.6 \%) \\
\end{array}$ & $>0.05$ & $>0.05$ & $>0.05$ \\
\hline $\begin{array}{l}\text { Pain in } \\
\text { bones }\end{array}$ & \begin{tabular}{|c|}
4 \\
$(9.1 \%)$ \\
\end{tabular} & $\begin{array}{c}2 \\
(2.5 \%)\end{array}$ & $\begin{array}{c}1 \\
(2.4 \%)\end{array}$ & $>0.05$ & $>0.05$ & $>0.05$ \\
\hline $\begin{array}{l}\text { Tooth } \\
\text { decay }\end{array}$ & $\begin{array}{c}2 \\
(4.5 \%) \\
\end{array}$ & $\begin{array}{c}2 \\
(2.5 \%) \\
\end{array}$ & - & $>0.05$ & $>0.05$ & $>0.05$ \\
\hline $\begin{array}{l}\text { Allergic } \\
\text { rash }\end{array}$ & $\begin{array}{c}9 \\
(20.5 \%) \\
\end{array}$ & $\begin{array}{c}25 \\
(31.6 \%) \\
\end{array}$ & $\begin{array}{c}12 \\
(29.3 \%) \\
\end{array}$ & $>0.05$ & $>0.05$ & $>0.05$ \\
\hline $\begin{array}{l}\text { Head- } \\
\text { aches }\end{array}$ & $\begin{array}{c}5 \\
(11.4 \%)\end{array}$ & $\begin{array}{c}5 \\
(6.3 \%)\end{array}$ & $\begin{array}{c}3 \\
(7.3 \%)\end{array}$ & $>0.05$ & $>0.05$ & $>0.05$ \\
\hline $\begin{array}{l}\text { Sleep } \\
\text { distur- } \\
\text { bance }\end{array}$ & $\begin{array}{c}4 \\
(9.1 \%)\end{array}$ & $\begin{array}{c}2 \\
(2.5 \%)\end{array}$ & $\begin{array}{c}1 \\
(2.4 \%)\end{array}$ & $>0.05$ & $>0.05$ & $>0.05$ \\
\hline
\end{tabular}

Celiac disease symptoms in children depending on degree and type of iron deficiency.

$P_{1}$ - significance of difference between groups of patients with IDA and LID;

$\mathrm{P}_{2}$ - significance of difference between groups of patients with IDA and with no ID:

$P_{3}$ - significance of difference between groups of patients with LID and with no ID.

A comparative anaysis revealed a number of important issues in celiac disease complicated with IDA. First, children with IDA, if compared to their counterparts with no ID, have diarrhea 1.7 times as often $(p<0.01)$, abdominal distention 1.7 times as often $(p<0.05)$, and a 3.4-time higher rate of complaintys associated with vomiting $(p<0.001)$. At the same time, the occurrence of poor appetite and chronic 
abdominal pain basically never depended on the presence and the type of ID ( $p>0.05)$.

On the other hand, quite natural was that children with celiac disease complicated with IDA manifested more prominent lagging in their physical development, due to which the number of patients who were underweight and of low height exceeded significantly that in the group with no ID. The rate of so-called minor symptoms of celiac disease in the groups under investigation revealed no substantial difference. Obviously, ID, as well as other deficiencies that result from celiac disease manifestation, will inevitably have a negative impact on the child's physical growth and psychomotor progress, thus leading to prominent asthenovegetative, and - more than seldom - to asthenoneurotic symptoms, eventually deteriorating the patient's life quality $[4,7,9]$.

The Table 2 offers a view on the outcomes of a laboratory examination involving patients with celiac disease depending on the iron supply status.

Table 2

Laboratory check-up outcomes for iron metabolism in children with celiac disease

\begin{tabular}{|l|c|c|c|c|c|c|}
\hline \multirow{4}{*}{ Indicator } & \multicolumn{3}{|c|}{$\begin{array}{c}\text { Degree and type } \\
\text { of ID }\end{array}$} & \multicolumn{4}{c|}{$\begin{array}{c}\text { Reliability } \\
\text { of difference }\left(\chi^{2}\right)\end{array}$} \\
\cline { 2 - 8 } & $\begin{array}{c}\text { IDA, } \\
n- \\
44\end{array}$ & $\begin{array}{c}\text { LID, } \\
n- \\
79\end{array}$ & $\begin{array}{c}\text { No } \\
\text { ID, } \\
n- \\
41\end{array}$ & $p_{1}$ & $p_{2}$ & $p_{3}$ \\
\hline SI, $\mu \mathrm{mol} / /$ & $\begin{array}{c}5.4 \\
\pm 0.3\end{array}$ & $\begin{array}{c}8.6 \\
\pm 0.3\end{array}$ & $\begin{array}{c}15.6 \\
\pm 0.4\end{array}$ & $<0.001$ & $<0.001$ & $<0.001$ \\
\hline SF, ng/ml & $\begin{array}{c}6.2 \\
\pm 0.5\end{array}$ & $\begin{array}{c}15.7 \\
\pm 1.0\end{array}$ & $\begin{array}{c}48.3 \\
\pm 2.0\end{array}$ & $<0.001$ & $<0.001$ & $<0.001$ \\
\hline $\begin{array}{l}\text { TIBC, } \\
\mu \mathrm{mol} / \mathrm{I}\end{array}$ & $\begin{array}{c}79.7 \\
\pm 0.5\end{array}$ & $\begin{array}{c}71.7 \\
\pm 0.5\end{array}$ & $\begin{array}{c}52.6 \\
\pm 0.7\end{array}$ & $<0.001$ & $<0.001$ & $<0.001$ \\
\hline $\begin{array}{l}\text { Transfer- } \\
\text { rin, g/l }\end{array}$ & $\begin{array}{c}3.9 \\
\pm 0.1\end{array}$ & $\begin{array}{c}3.3 \\
\pm 0.1\end{array}$ & $\begin{array}{c}2.6 \\
\pm 0.1\end{array}$ & $<0.001$ & $<0.001$ & $<0.001$ \\
\hline TSAT, \% & $\begin{array}{c}6.8 \\
\pm 0.3\end{array}$ & $\begin{array}{c}12.0 \\
\pm 0.4\end{array}$ & $\begin{array}{c}30.1 \\
\pm 1.0\end{array}$ & $<0.001$ & $<0.001$ & $<0.001$ \\
\hline
\end{tabular}

$P_{1}$ - significance of difference between groups of patients with IDA and LID;

$\mathrm{P}_{2}$ - significance of difference between groups of patients with IDA and with no ID;

$P_{3}$ - significance of difference between groups of patients with LID and with no ID.

The data in Table 2 show that as sideropenia progresses in children with celiac disease, they reveal disturbed concentrations of iron-containing proteins as well as other laboratory signs of a decrease in the transport and tissue pool of iron, which are pathognomonic for ID.

A number of published items point at parallelism to be observed between anti-TG2, AGA and the severity degree of anemia [5, 19].

In our group of patients, the level of specific serological markers in patients with celiac disease, depending on the degree and the type of ID, was different. The average titer EMA (IgA, IgG) in children with IDA was 1213.3 \pm 221.9 $\mathrm{U} / \mathrm{I}$, which was significantly above that in patients with LID $(637.8 \pm 123.8 \mathrm{U} / \mathrm{I}(\mathrm{p}<0.05))$ and with no ID $(645.3 \pm 294.7$ $\mathrm{U} / \mathrm{I}(\mathrm{p}<0.05))$. There was a direct correlation detected between the antibody titer to endomysium and the level of transferring $(r=0.45, p<0.01)$.

The differences in the anti-TG2 were rather insignificant. The average level of anti-TG2 IgA in the groups with IDA, LID, and with no ID, was $75.4 \pm 15.5 \mathrm{U} / \mathrm{I}$, $77.4 \pm 10.4 \mathrm{U} / \mathrm{I}$, and $56.8 \pm 10.0 \mathrm{U} / \mathrm{I}$, respectively $(p>0.05)$. The difference in the anti-TG2 IgG level was even less significant $-37.6 \pm 10.0 \mathrm{U} / \mathrm{I}, 25.0 \pm 3.8 \mathrm{U} / \mathrm{I}$, and 23.9 \pm 3.8 $\mathrm{U} / \mathrm{I}(\mathrm{p}>0.05)$. Yet, correlation analysis revealed a reverse correlation between the anti-TG2 IgA level and SF $(r=-0.28, p<0.02)$, as well as direct correlation between the anti-TG2 IgA and transferrin $(r=0.31, p<0.01)$.

Proof to close interrelation between malabsorption syndrome and the degree of anemia may be found in respective literature focusing on increasing ID rate along with atrophy progress in the small intestine [8, 13].

On Figure shows the structure of morphological changes in children with celiac disease depending on the degree and the type of ID. Patients with IDA had total atrophy of villi prevailing, which matched Stage $3 \mathrm{C}$ by Marsh, while Stage 3A was diagnosed in $5.0 \%$ of cases only. In children with IDA, Stage 3C by Marsh was detected 2.0 times, and in children with no ID - 3.8 times less often compared to those with IDA. Correlation analysis helped reveal a reverse link between the stage of empty intestine atrophy and the hemoglobin level $(r=-0.26, p<0.02)$, the level of $\mathrm{SI}$ $(r=-0.32, p<0.005)$, the level of $S F(r=-0.50, p<0.001)$. It is obvious that in patients with celiac disease, progressing atrophy of EIM leads not only to reduced transport pool of iron but also to deep depletion of its tissue reserve, which become complete with IDA development.

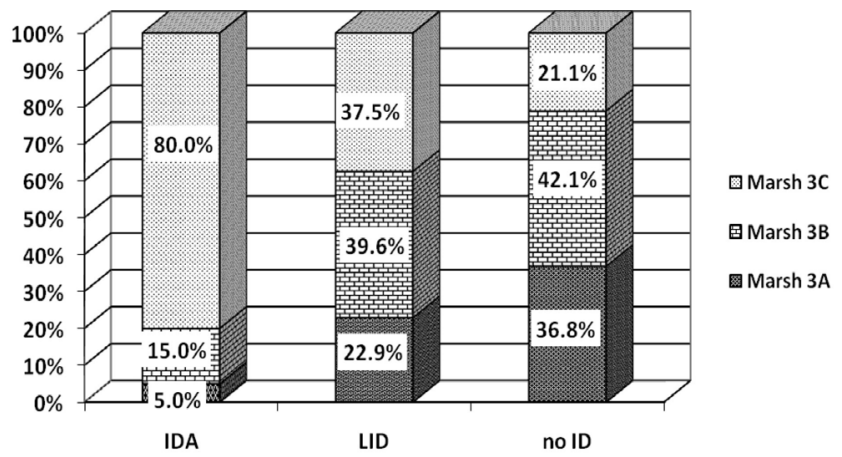

Fig. The structure of atrophy stages in EIM

(by Marsh-Oberhuber) in patients with celiac disease

depending on the degree and the type of iron deficiency

The occurrence rate of celiac disease in patients with IDA varies, according to different sources, falling in the range between $5-9 \%$ to $21.3 \%$, while the list is topped by patients with refractory anemia (refractivity is defined as lack of increase in the hemoglobin level by $10 \mathrm{~g} / \mathrm{l}$ and more after a 2-month treatment with peroral iron preparations) $[12,15]$. N. Sharma et al. report that celiac disease was diagnosed (with serological and morphological methods) in $28 \%$ of cases suffering from refractory anemia [23].

Literature offers often opposite ideas regarding the need for serological screening of celiac disease among patients with anemia $[6,14]$. Despite lots of controversy in interpreting diagnostic value of anemia for celiac disease, which are due to employing serological methods with varying sensitivity and specificity, most researchers agree that very frequently developing ID and its manifest expression - IDA - stand an important pathogenetic component to the disease so a detailed laboratory examination of the transport and tissue pool of iron may serve a rather reliable predictor in verifying celiac disease $[3,6,14,20,23]$. The outcomes of our study, too, offer a piece of convincing proof to this stance.

Verification of IDA and LID in patients with no malabsorption syndrome is an indication for ferrotherapy, while its duration and the doses to be used shall depend not on the severity of anemia alone yet also on the iron preparations to be administered. The issue of the need and the duration of iron-medication treatment for patients with celiac disease after they are put on gluten-free diet 
(GFD), still remains open to discussion [10, 18]. Most authors believe that strict dieting resulting in restored morphological structure and the absorbing capacity of the small intestine mucosa may reverse anemia as well as create iron reserves that tissues need $[11,16]$. However, there is also another point of view stating that GFD, which is eliminational in itself, is a diet that is not balanced sufficiently on a number of micronutrients iron being one of them, so even if followed strictly, such a diet will not stop and prevent the progress of ID in children for sure [25].

Conclusions. The outcomes obtained through clinical, morphological and serological check-ups revealed a high rate of ID in children with celiac disease $(75.0 \%)$, while the balance of IDA and LID, in view of no serious gender difference, appears as 1:1.9. The clinical presentation of celiac disease complicated with IDA is associated with significant prominence of gastro-

\section{References}

1. Belmer S. V., Gasilina T. V. Tseliakiya: iskhody i novye podkhody k diagnostike. Lechashchiy vrach. - Therapist. 2012;8:56-60.

2. Diagnostika i lechenie zhelezodefitsitnoy anemii u detey i podrostkov (posobie dlya vrachey) / Pod red. A. G. Rumyantseva, I. N. Zakharovoy. M.: OOO «KONTI PRINT»; 2015. 76 p.

3. Zakharova I. N., Berezhnaya I. V., Dmitrieva Yu. A., Machneva E. B. Anemiya pri patologii zheludochno-kishechnogo trakta u detey: differentsialnyy diagnoz. Farmateka. Farmateka.2014;11:39-47

4. Klimov L. Ya., Stoyan M. V., Kuryaninova V. A., Kashnikov V. S., Atanesyan R. A. et al. Antropometricheskie pokazateli detey $\mathrm{v}$ periode klinicheskoy manifestatsii tseliakii. Eksperimental'naya $i$ klinicheskaya gastroenterologiya - Experimental and Clinical Gastroenterology. 2013;1:55-59.

5. Parfenov A. I., Akhmadullina O. V., Sabelnikova E. A., Belostotskiy N. I., Gudkova R. B. et al. Aktivnost' karbogidrazkakmarkervosstanovleniya slizistoy obolochki tonkoy kishki u bol'nykh tseliakiey. Terapevticheskiy arkhiv. - Therapeutic archives. 2015;87(2):24-29.

6. Polyakova S. I., Anushenko A. O., Bakanov M. I., Smirnov I. E. Analiz i interpretatsiya pokazateley obmena zheleza pri raznykh formakh patologii u detey. Rossiyskiy pediatricheskiy zhurnal. - Russian Journal of Pediatrics. 2014;17(3):17-23.

7. Rumyantsev A. G., Zakharova I. N., Chernov V. M., Tarasova I. S., Zaplatnikov A. L. et al. Rasprostranennost' zhelezodefitsitnykh sostoyaniy i faktory, na nee vliyayushchie. Meditsinskiy sovet. - Medical advice. 2015;6:62-66.

8. Filatov L. B., Berman V. B. Zhelezodefitsitnaya anemiya kak sledstvie narusheniya vsasyvaniya zheleza pri tseliakii. Klinicheskaya onkogematologiya. - Clinical oncohematology. 2010;3(3):284-288.

9. Tseliakiya u detey / Pod red. S. V. Bel'mera, M.O. Revnovoy. M.: ID «MEDPRAKTIKA-M»; 2013. 416 p.

10. Barker J. M., Liu E. Celiac disease: pathophysiology, clinical manifestations, and associated autoimmune conditions. Adv Pediatr. 2008;55:349-365.

11. Catassi C., Kryszak D., Louis-Jacques O., Duerksen D. R., Crowe S. E. Detection of Celiac disease in primary care: a multicenter case-finding study in North America. Am J Gastroenterol. 2007:102(7):1454-1460.

12. De Caterina M., Grimaldi E., Di Pascale G., Salerno G., Rosiello A. The soluble transferrin receptor (sTfR)-ferritin intestinal symptoms and more delayed physical progress compared to children with no ID.

An analysis of morphological change shows that total atrophy in the empty intestine mucosa (matches Stage 3C by Marsh-Oberhuber) can be found in patients with IDA in $80.0 \%$ of cases while in children with no ID this rate is only $21.1 \%$. Aggravation of atrophy in the small intestine that is to be found in children and adolescents in case of undiagnosed celiac disease comes along with gradual depletion of the transport, and then of the tissue iron pool.

Therefore, identifying IDA in children going through an active stage of celiac disease will serve a reliable criteria witnessing serious atrophy in the small bowel; it also is associated with prominent delay in physical progress and takes monitoring of iron metabolism including indicators of transport and markers of tissue iron reserve through sticking the course of a gluten-free diet.

index is a potential predictor of celiac disease in children with refractory iron deficiency anemia. Clin Chem Lab Med 2005:43(1):38-42.

13. Emami M. H., Karimi S., Kouhestani S. Is routine duodenal biopsy necessary for detection of celiac disease in patients presenting with iron deficiency anemia? Int J Prev Med. 2012:3(4):273-277.

14. Ertekin V., Tozun M. S., Kucuk N. The prevalence of celiac disease in children with iron-deficiency anemia. Turk $J$ Gastroenterol. 2013;24(4):334-338.

15. Hershko C., Patz J. Ironing out the mechanism of anemia in celiac disease. Haematologica. 2008;93(12):17611765.

16. Hoffenberg E. J., MacKenzie T., Barriga K. J., Eisenbarth G. S., Bao F. A prospective study of the incidence of childhood celiac disease. J Pediatr. 2003;143(3):308-314.

17. Klimov L. Ya., Kuryaninova V. A., Stoyan M. V., Asaturova D. V., Gerasimenko E. S. Duration of latent period and iron deficiency development in children with celiac disease. Medical News of North Caucasus. 2014;9(2):148-151.

18. Meazza C., Pagani S., Laarej K., Cantoni F., Civallero P. Short stature in children with coeliac disease. Pediatr Endocrinol Rev. 2009;6(4):457-463.

19. Mičetić-Turk D., Ornik T. Epidemiology of coeliac disease. International Coeliac disease Meeting. Proceedings of international Coeliac Disease Meeting, September 2007; Maribor: University Medical Center Maribor; 2007. 37-48.

20. Murray J. A., McLachlan S., Adams P. C., Eckfeldt J. H., Garner C. P. et al. Association between celiac disease and iron deficiency in Caucasians, but not non-Caucasians. Clin Gastroenterol Hepatol. 2013;11(7):808-814

21. Reilly N. R., Green P.H. Epidemiology and clinical presentations of celiac disease. Semin Immunopathol. 2012;34(4):473-478.

22. Schuppan D., Junker Y., Barisani D. Celiac disease: from pathogenesis to novel therapies. Gastroenterology. 2009;137(6):1912-1933.

23. Sharma N., Begum J., Eksteen B., Elagib A., Brookes M. Differential ferritin expression is associated with iron deficiency in celiac disease. Eur J Gastroenterol Hepatol. 2009;21(7):794-804.

24. Telega G., Bennet T. R., Werlin S. Emerging new clinical patterns in the presentation of celiac disease. Arch Pediatr Adolesc Med. 2008;162(2):164-168.

25. Zamani F., Mohamadnejad M., Shakeri R., Amiri A., Najafi S. Gluten sensitive enteropathy in patients with iron deficiency anemia of unknown origin. World J Gastroenterol. 2008;14(48):7381-7385.

\section{About authors:}

Klimov Leonid, MD, cms, Associate Professor, Head of Department of Pediatrics; tel.: +79289630261; e-mail: klimov_leo@mail.ru

Stoyan Marina, MD, cms, Assistant Lecturer, Department for Departmental Pediatrics;

tel.: +79282447990; e-mail: marina-stoyan@mail.ru

Kuryaninova Victoria, MD, cms, Assistant Lecturer, Department for Propaedeutics of Child Diseases;

tel.: +79282938069; e-mail: vichkak@mail.ru

Kashnikov Vyacheslav, MD, PhD, Chief Medical Officer ofs Philippsky Child Clinical Hospital;

tel.: +79054961335; e-mail: 721771@mail.ru

Botasheva Valentina, MD, PhD, Professor, Head of Department for Pathological Anatomy; tel.: +79188766118 